\title{
PROPOSALS FOR IMPROVEMENT OF LOGISTIC SUPPORT OF STATE DEFENSE FORCES UNIT THROUGH A VISUAL GRAPHIC REPRESENTATION OF THE SITUATION AND THE APPLICATION OF THE OPERATION RESEARCH MATHEMATICAL MODELS
}

\begin{abstract}
The subject matter of the article is the logistical support of the state defense forces unit in the performance of its assigned tasks. The goal of the study is to develop of mathematical models for the complex analysis of the basic forces and means of logistical support and to increase efficiency of planning of military unit equipment with means of logistical support depending on change of a tactical situation. The tasks to be solved are: to formulate the logistics optimizing problem for the professional activity of the state defense forces unit, which includes the main units and technical support ones, in terms of operations research; to substantiate the possibility of qualifying the material support of the state defense forces unit and the formation of a transport costs matrix using $\mathrm{ABC}$ analysis; to identify technical solutions regarding ways to visualize information for a make-decision person on logistical support and formulation of output information for the users in the required format. General scientific and special methods of scientific knowledge are used. The following results are obtained: On the basis of use of modern principles of stocks management the optimizing task of the management of logistical support for the State defense forces wheeled and tracked vehicles unit can be formulated as an integer problem of linear programming of transport type. according to certain features of the flow nature of logistics support in the competence of the deputy commander of the Deputy Commander of the SDF armaments unit for the input information is sufficient to hold the $\mathrm{ABC}$-analysis and on its basis to form a matrix of transport costs. visualization of information in graphical mode will enable to implement interactive display of material and technical support equipment deployment areas, locations of collection point of damaged vehicles, maneuvering routes, evacuation of damaged vehicles, etc. Conclusions. The task of finding the optimal logistics support plan for a State defense forces wheeled and tracked vehicles unit can also be classified as transport and solved by the well-known line programming methods. According to certain features of the flow nature of the drug in the competence of the deputy commander of the State defense forces unit for input information is sufficient to conduct an $\mathrm{ABC}$-analysis and on its basis to form a matrix of transport costs. Visualization of information in the graphical mode will allow to realize interactive display of areas of location of material and technical support equipment units, places of assembly point of the damaged cars, ways of maneuver, delivery and evacuation of the damaged samples of weapons, etc.
\end{abstract}

Keywords: logistics support, wheeled and tracked vehicles, material and technical support equipment, integer problem of linear programming of transport type

\section{Introduction}

Formulation of the problem and research tasks. In the conditions of transformation of managerial orientation in the direction to Euro-Atlantic integration, the application of the operation research mathematical apparatus acquires a new meaning.

The concept of material flow management, the essence of which lies in the integration of all functional spheres associated with the passage of the material flow from producer to consumer into a single complex, is called "logistic" and has found its functional application in the military sphere.

The development of new mathematical models to provide a comprehensive analysis of the main logistical support (LS) forces and improve the effectiveness of planning for the equipment of a military unit with material and technical support equipment (MTE) depending on changes in the tactical environment seems relevant in this regard.

Analysis of recent research and publications on the above issues shows the relevance of the study.

In [1] it was formalized a space-geometric configuration of the logistic support system for military training based on the analysis of signs (links) between elements of the system and objects of the military order.

The system is supported and a class of mathematical methods (models) for determining the location of the elements of the system on the area is defined.

The issue of determining the approach to the positioning of evacuation (repair and evacuation) units in the operational zone (area) of responsibility for the minimum total distance to the elements of the combat order is considered in $[2,3]$.

The goal of the study is to develop of mathematical models for the complex analysis of the basic forces and means of logistical support and to increase efficiency of planning of military unit equipment with means of logistical support depending on change of a tactical situation.

To achieve this goal the following research tasks are solved:

- to formulate the logistics optimizing problem for the professional activity of the state defense forces (SDF) unit, which includes the main units and technical support ones, in terms of operations research;

- to substantiate the possibility of qualifying the material support of the state defense forces division and 
the formation of a transport costs matrix using $\mathrm{ABC}$ analysis;

- to identify technical solutions regarding ways to visualize information for a make-decision person on logistical support and formulation of output information for the users in the required format.

\section{Main material}

1. Formulation of the problem of optimizing logistic support for the operational activities of the state defense forces, which includes the main units and technical support units, in the terms of operations research.

Logistics is a rather new notion for us: the bibliography has not yet defined it as a separate scientific field in the Ukrainian enterprises that are only now beginning to pay it some attention, and the Ukrainian literary sources devoted to this problem are represented in small numbers.

Nevertheless, the applied warehouse of logistic research is widely reflected in stock management methods in various industries. The most efficient solution of logistic problems is achieved by using a powerful mathematical apparatus of operations research.

As we know, the functioning of the units of the state defense forces (SDF) must be provided with certain resources: stocks of material and technical equipment (MTE), availability of repair bodies, maintenance personnel, etc. [4, 5].

Optimization of resource allocation is often carried out according to the specified criteria and certain limitations. These tasks can be included in the class of transport tasks of linear programming.

Suppose that in the SDF area of responsibility there are $n$ units of wheeled and tracked vehicles (WTV), each $j$-th of which requires the provision of MTE resources in an amount not exceeding $b_{j}$, $j=1, \ldots ., n$.

The operation of the main units is provided by $m$ types of logistics units, each of which has a resource reserve $a_{i}, i=1, \ldots ., m$.

The cost of supplying an MTE unit from $i$ to $j$ point is $c_{i j}$.

The matrix $C_{i j}=\left(c_{i j}\right), i=1, \ldots ., m, j=1, \ldots, n$ is sometimes called the transport cost matrix. Its values are determined by the activity orientation of the enterprise.

When forming the matrix $\mathrm{C}_{i j}$ can be taken into account not only the material cost of transportation of a certain number of units of MTE resource and time, risks or priority of displacement. The task is to create a resource allocation plan that meets the needs and does not exceed the available capacity.

Denote by $x_{i j}, \quad i=1, \ldots ., \quad m, \quad j=1, \ldots ., \quad n$ - the movement of a number of resource units from the $i$-th support unit to the $j$-th main unit.

Then the total cost will be as follows:

$$
\sum_{i=1}^{m} \sum_{j=1}^{n} c_{i j} x_{i j}
$$

The optimal transportation plan $X^{*}$ will be called a plan that provides a minimum amount of costs for the transportation of all resources.

It should be noted that the semantic load of coefficients $\quad c_{i j}, \quad i=1, \ldots ., m, \quad j=1, \ldots ., n$ can vary depending on the specifics and conditions of the tasks performed by the WTV unit. Thus, it is possible to minimize time, fuel costs, risk, maximize efficiency, etc.

Thus, of the problem of optimizing logistic support for the operational activities of the state defense forces units on the basis of using modern principles of inventory management can be formulated as an integer problem of linear programming of transport type:

Find a set

$$
X^{*}=\left\{x_{i j}^{*}\right\}, i=1, \ldots, m, j=1, \ldots, n,
$$

such that minimizes the objective function

$$
F(x)=\sum_{i=1}^{m} \sum_{j=l}^{m} c_{i j} x_{i j} \rightarrow \min
$$

and satisfies the conditions

$$
\begin{gathered}
\sum_{i=1}^{m} x_{i j}=b_{j}, \\
\sum_{j=1}^{n} x_{i j}=a_{i}, \\
x_{i j} \geq 0, x_{i j} \in Z, \\
i=1, \ldots, m, \\
j=1, \ldots ., n,
\end{gathered}
$$

We should note that expression (2) refers to the provision of the WTV units with the full amount of MTE equipment.

Similarly, view (3) means the condition of full use of resources.

Taking into account the actual conditions of LS, expressions (2) and (3) can be written as

$$
\begin{aligned}
& \sum_{i=1}^{m} x_{i j} \leq b_{i}, \\
& \sum_{j=1}^{n} x_{i j} \leq a_{i},
\end{aligned}
$$

Under the condition

$$
\sum_{i=1}^{m} a_{i} \neq \sum_{j=1}^{n} b_{j}
$$

problem (1)-(8) is called open, but can be reduced to closed by piecemeal methods. 
In the authors' opinion, it is promising to use the results of $\mathrm{ABC}$ analysis to form the coefficients $c_{i j}$, $i=1, \ldots, m, j=1, \ldots ., n$., namely, to take into account the hierarchy of LS of the main units and relevant logistics support ones.

Proceeding from this, as a focus of further research can be requested a more sophisticated formulation of the transport problem, namely the introduction of limits of the form.

$$
\begin{gathered}
\sum_{i=1}^{m} r_{i j} x_{i j} \leq b_{i} \\
\sum_{j=1}^{n} r_{i j} x_{i j} \leq a_{i} \\
i=1, \ldots ., m, \\
j=1, \ldots ., n,
\end{gathered}
$$

The task of finding the optimal LS plan for a state defense forces wheeled and tracked vehicles unit can also be classified as transport and solved by the wellknown line programming methods [6].

2. Possibility to qualify the material support of the SDF unit and to form a matrix of transport costs by means of $\mathrm{ABC}$ analysis.

The authors consider the possibility to qualify the material support of the state defense forces division by means of ABC analysis, a method that allows to classify resources depending on their significance. The classification is based on the Pareto principle.

Regarding $\mathrm{ABC}$ analysis, the Pareto principle is the following: reliable control of $20 \%$ of positions allows $80 \%$ control of the system.

In business, the $\mathrm{ABC}$-analysis principle and the Pareto principle are most often used in logistics for inventory management: regarding stocks of hardware, components, suppliers, customers, etc. define:

For example, ranking stocks by value, we can

category "A" (they say $10 \%$ of stocks, the value of which is $70 \%$ of total production),

category "B" (20\% of stocks, which account for $20 \%$ of total production);

category "C" (the value of which is $100 \%$ ).

Thus, logistics managers should focus on the management of category " $A$ " stocks.

With respect to "B" stocks, the control can be periodic, with "C" stocks being more generous [7, $8]$.

By analogy the authors propose to conduct $\mathrm{ABC}$ analysis and on its basis form transport costs matrix $C_{i j}=\left(c_{i j}\right), i=1, \ldots ., m, j=1, \ldots ., n$ for determined risks of flow nature of LS of state defense forces unit.

Thus, as input information in the competence of the Deputy Commander of the state defense forces armaments unit, it is proposed to consider:

- availability, condition of armor and military equipment (MTE);
- foreseen costs and losses, the need for and the possibility of their comprehensive maintenance (MTE) and repair $(\mathrm{R})$;

- training and staffing of specialists, mechanics drivers and drivers for other units;

- possibility of using local industrial and economic base (resources).

Using mathematical apparatus of factor analysis is proposed to make the obtained data processing to form their ABC - hierarchy.

Forming such a matrix manually is a very important process, so there are systems for its automation $[9,10]$.

3. Defining technical solutions for ways of visualization of information for the makedecisions person on logistics and the formation of source information for users in the desired format.

The main idea of LS improvement is to process the input and output information in an interactive mode, operational and optimal management of material flows. In this regard, the authors consider it appropriate to visualize the information for the PL decision maker and generate the output information for the users in the required format.

The "overlay" of the resulting solution on the information of the mapping services and technologies is proposed using Cash- and MIPmapping procedures.

This will enable use of cached copies of map sheets at different scaling levels and visualize the solution at the cost of efficient use of information resources.

Cached copies of mapsheets of different scales can be stored in a virtual storage and used by control signals if there is an order to visualize the information of the mapping service.

In this process, the image quality of map sheets with different levels of detail is improved by using textures with different separation capacities for different objects of the same image, depending on their size and depth.

Thus, visualization of information in graphical mode will enable to implement interactive display of MTE deployment areas, locations of collection point of damaged vehicles, maneuvering routes, evacuation of damaged vehicles, etc.

The prerequisite for technical implementation of modernization of LS is the use of new information technologies, such as onboard information systems of the "Command and Control" class (e.g., Hermes-C2), which can be installed directly on armored vehicles $[11,12]$.

An airborne information system integrated with Aselsan and Harris communications equipment can also be effective for LS tasks.

\section{Conclusions}

1. The task of finding the optimal logistics support plan for a State defense forces wheeled and tracked vehicles unit can also be classified as 
transport and solved by the well-known line programming methods.

2. According to certain features of the flow nature of the drug in the competence of the deputy commander of the state defense forces unit for input information is sufficient to conduct an $\mathrm{ABC}$-analysis and on its basis to form a matrix of transport costs.
3. Visualization of information in the graphical mode will allow to realize interactive display of areas of location of material and technical support equipment units, places of assembly point of the damaged cars, ways of maneuver, delivery and evacuation of the damaged samples of weapons, etc.

\section{REFERENCES}

1. Gulyaev, A.V. (2010), "The choice of criteria for assessing the technological efficiency of recovery methods of armored weapons and military equipment", Systemy ozbroyennya i viyskova tekhnika, vol. 4, no. 24, pp. 36-39.

2. Chornyy, M.V. and Dolgov, R.V. (2014), "Positioning of evacuation (repair-evacuation) bodies of military formation on the ground", Systemy ozbroyennya i viyskova tekhnika, vol. 1, no. 37, pp.88-92.

3. Sytnyk, V.F. (2004), Decision Support Systems, Tutorial tool, KNEU, Kyiv, UA, 614 p.

4. Rolin, I.F., Morozov, I.Ye. and Myn'ko, O.V. (2017), "The content of the main terms in the field of logistics of military formations", Systemy ozbroyennya i viyskova tekhnika, no 1(49), pp. 61-64.

5. Khazanovych, O.I., Ishutin, I.S. and Ivchenko, V.V. (2010), Tekhnichne zabezpechennya viys'k (syl): navch. posib. [Technical support of troops (forces): a textbook], NUOU im. Ivana Chernyakhovs'koho, Kyyiv, UA.

6. Venttsel', Ye. S. (1972), Issledovaniye operatsiy [Operations Research], Sov.Radio, Moscow, SU.

7. Hanssman, F (1966), Primeneniye matematicheskikh metodov v upravlenii proizvodstvom i zapasami [Operations Research in Production and Inventory Control], Translated by Yudin, D, Progress, Moscow, SU.

8. Koch, R (2004), Printsip 80/20, [The 80/20 Principle], Popurri, [Online], available at: http://www.popuri.ru/site

9. Hulyayev, A. V., Zubaryev, O. V., Kanishchev, V. V. and Kolodyazhnyy, V. B. (2016), "Improving the efficiency of the system of maintenance and repair of weapons and military equipment", Ozbroyennya ta viys'kova tekhnika, no 2(10), pp.4348.

10. Goloshchapov, I. M. (1989), Ekspluatatsiya bronetankovogo vooruzheniya i tekhniki, [Operation of armored weapons and equipment], Moscow, SU.

11. Onboard information system "HERMES-c2 (Command and Control) [Online], available at: https://www.everest.ua/bortova-informatsiyna-systema-hermes-c2/

12. Joint Logistics (JP 4-0) [Online], available at: http://www.globalsecurity.org/military/library/policy/dod/joint/jp4_0_2008.pdf.

Received (Надійшла) 20.07.2021

Accepted for publication (Прийнята до друку) 25.08.2021

\section{Розроблення пропозицій удосконалення логістичного забезпечення підрозділу сил оборони держави через візуальне-графічне зображення обстановки та застосування математичних моделей дослідження операцій}

О. А. Макогон, Ю. В. Бабкін, К. Л. Баканов, В. І. Москаленко, М. В. Мосійчук, С. В. Піскун

Анотація. Предметом вивчення в статті $\epsilon$ логістичне забезпечення підрозділу сил оборони держави при виконанні ним завдань за призначенням. Метою дослідження є розроблення математичної моделей для комплексного аналізу основних сил і засобів логістичного забезпечення та підвищити ефективність планування оснащення військового підрозділу засобами матеріально-технічного забезпечення в залежності від зміни тактичної обстановки. Завдання дослідження: формулювання задачі оптимізації логістичного забезпечення фахової діяльності підрозділу сил оборони держави, до складу якого входять основні підрозділи та підрозділи технічної підтримки, у термінах дослідження операцій; обгрунтувати можливість кваліфікації матеріального забезпечення підрозділу сил оборони держави та формування матриці транспортних витрат за допомогою $\mathrm{ABC}$-аналіза; визначення технічних рішень щодо шляхів візуалізацію інформації для особи, що приймає рішення по логістичному забезпеченню та формування вихідної інформації для користувачів у потрібному форматі. Методологічною основою дослідження стали загальнонаукові та спеціальні методи наукового пізнання. Отримані такі результати. Задача оптимізації логістичного забезпечення фахової діяльності підрозділу сил оборони держави сформульована у термінах дослідження операцій. Показана кваліфікація матеріального забезпечення підрозділу сил оборони держави для формування матриці транспортних витрат за допомогою АВС-аналіза. Висновки. Задача оптимізації управління логістичним забезпеченням підрозділу колісногусеничних машин підрозділу сил оборони держави на основі використання сучасних принципів управління запасами може бути сформульована як цілочисельна задача лінійного програмування транспортного типу. За визначеними рисами потокового характеру логістичного забезпечення у компетенції заступника командира підрозділу сил оборони держави вхідна інформації $\epsilon$ достатньою для проведення АВС-аналізу та на його основі формування матриці транспортних витрат. Візуалізація інформації у графічному режимі надасть змогу реалізувати інтерактивне відображення районів розташування підрозділів матеріально-технічного забезпечення, місця збірного пункту пошкоджених машин, шляхи маневру, підвозу та евакуації пошкоджених зразків озброєння та військової техніки, тощо.

Ключові слова: логістичне забезпечення, колісно-гусеничні машини, матеріально-технічне забезпечення, цілочисельна задача лінійного програмування транспортного типу. 